\title{
CYP1A2 wt Allele
}

National Cancer Institute

\section{Source}

National Cancer Institute. CYP1A2 wt Allele. NCI Thesaurus. Code C52350.

Human CYP1A2 wild-type allele is located within $15 q 24$ and is approximately $8 \mathrm{~kb}$ in length. This allele, which encodes cytochrome P450 1A2 protein, is involved in the metabolism of drugs and xenobiotics. Certain allelic variants of the CYP1A2 gene contribute to the poor metabolizer phenotype, which is characterized by the inability to use cytochrome P450-dependent metabolic pathways for drug elimination. Functional polymorphisms in the CYP1A2 gene may increase the risk of pancreatic cancer in smokers. 